\title{
PENDIDIKAN NILAI: \\ DI SEKOLAH MADANIA KABUPATEN BOGOR
}

\section{Educational of Value: in Madania School, Bogor Regency}

\author{
Mulyana \\ Balai Penelitian dan Pengembangan Agama Jakarta \\ Jl. Jl. Rawa Kuning No. 6 Pulo Gebang Cakung Jakarta Timur \\ Email: yana.litbangjkt@gmail.com
}

Naskah diterima tanggal 27 Maret 2015. Naskah direvisi tanggal 30 April 2015 Naskah disetujui tanggal 03 November 2015

\begin{abstract}
Abstrak
Paper ini menyajikan hasil penelitian terhadap program Pendidikan Menghidupkan Nilai yang dilakukan sejumlah elemen masyarakat. Penelitian dilakukan dengan melakukan studi kasus terhadap implementasi program tersebut di Sekolah Madania, Parung, Bogor. Penelitian ini mencoba mengkaji apakah program Pendidikan Menghidupkan Nilai dapat menjadi model yang berguna untuk meningkatkan kualitas pembelajaran Pendidikan Agama Islam (PAI) di sekolah. Hasil studi ini memperlihatkan bahwa program Pendidikan Menghidupkan Nilai telah memberi hasil positif yang teramati dalam perubahan perilaku tenaga pendidik maupun siswa terkait sejumlah nilai yang dipelajari, seperti kejujuran, penghargaan, toleransi, dan tanggung jawab. Berdasarkan hasil riset ini, peneliti menyimpulkan bahwa Pendidikan Menghidupkan Nilai, terutama pada aspek pendekatan dan metodenya, dapat menjadi model bagi pembelajaran PAI di sekolah.
\end{abstract}

Kata kunci: pendidikan menghidupkan nilai, pendidikan karakter, pendidikan agama Islam (PAI), Sekolah Madania

\begin{abstract}
This paper presents the results of the research on Education Program in Living Values conducted a number of elements of society. The study was conducted by doing a case study to the implementation of the program at Madania school, Parung, Bogor. This study investigated whether Education Program in Living Values can become useful model in improving the quality of learning of Islamic Education (PAI) at school. The results showed that this program has given positive results observed in behavior changes of the teachers and the students related to a number of values studied, such as honesty, respect, tolerance and responsibility. Based on the results, the researcher concluded that Education Program in Living Values, especially in the aspect of the approach and method, can be a model for Islamic Education (PAI) learning at school.
\end{abstract}

Keywords: Education Program in Living Values, character education, Islamic Education (PAI), Madania School

\section{PENDAHULUAN}

$\mathrm{D}$ alam dokumen Rencana Pembangunan Jangka Panjang Nasional Tahun 20052025, yang ditetapkan melalui UndangUndang No. 17 Tahun 2007, dinyatakan bahwa visi pembangunan nasional tahun 2005-2025 adalah terwujudnya "Indonesia yang mandiri, maju, adil, dan makmur." Butir pertama yang dirumuskan sebagai misi pembangunan untuk mencapai visi pembangunan nasional tersebut adalah "mewujudkan masyarakat berakhlak mulia, bermoral, beretika, berbudaya, dan beradab berdasarkan falsafah Pancasila." Secara lebih spesifik, misi tersebut ditempuh dengan cara "memperkuat jati diri dan karakter bangsa melalui pendidikan yang bertujuan membentuk manusia yang bertaqwa kepada Tuhan Yang Maha Esa, 
mematuhi aturan hukum, memelihara kerukunan internal dan antarumat beragama, melaksanakan interaksi antarbudaya, mengembangkan modal sosial, menerapkan nilai-nilai luhur budaya bangsa, dan memiliki kebanggaan sebagai bangsa Indonesia dalam rangka memantapkan landasan spiritual, moral, dan etika pembangunan bangsa".

Berdasarkan pernyataan misi tersebut dapat disimpulkan bahwa upaya memperkuat jati diri dan karakter bangsa sesungguhnya merupakan misi utama dan prioritas dalam keseluruhan upaya pembangunan nasional. Hal ini dapat dipahami mengingat upaya untuk mewujudkan kemakmuran yang sebesar-besarnya bagi seluruh rakyat Indonesia tidak akan tercapai jika hal itu tidak ditopang dengan keberadaan bangsa yang memiliki jati diri dan karakter yang kuat.

Namun, ironisnya fenomena yang terjadi saat ini justru memperlihatkan rapuhnya jati diri dan karakter pada sebagian elemen masyarakat Indonesia, baik di tingkat elite maupun massa. Hari demi hari berbagai kasus korupsi yang melibatkan para pejabat, politisi, pelaku usaha, bahkan kalangan akademisi terus menghiasai pemberitaan berbagai media massa. Sementara itu di sisi masyarakat umum, berbagai kasus konflik kekerasan, intoleransi, kriminalitas, penyalahgunaan narkoba, dan tawuran antar pelajar-untuk menyebut beberapa kasus-masih terus menghiasi kehidupan sosial masyarakat.

Sebagai respon terhadap kondisi karakter bangsa yang masih sangat memprihatinkan tersebut, pemerintah sendiri telah berupaya untuk mengambil inisiatif untuk memprioritaskan pembangunan karakter bangsa. Inisiatif tersebut antara lain telah dirumuskan dalam bentuk Kebijakan Nasional Pembangunan Karakter Bangsa Tahun 2010-2025, yang disusun oleh berbagai pemangku kepentingan yang melibatkan lembaga kementerian, lembaga nonkementerian maupun lembaga nonpemerintah (Pemerintah RI 2010). Pembangunan karakter bangsa melalui pendidikan penting dicermati lebih jauh karena, seperti disebutkan dalam dokumen kebijakan tersebut, pendidikan merupakan "tulang punggung strategi pembentukan karakter bangsa" (Pemerintah RI 2010, 29). Pentingnya pendidikan dalam pembangunan karakter bangsa sesungguhnya sejalan dengan fungsi dan tujuan pendidikan nasional (Pasal 3 UU No. 20 Tahun 2003).

Pada tingkat mikro, pendidikan karakter berpusat pada satuan pendidikan, yang selanjutnya dibagi dalam empat pilar, yakni kegiatan belajarmengajar di kelas, kegiatan keseharian dalam bentuk pengembangan budaya satuan pendidikan; kegiatan ko-kurikuler dan/atau ekstra kurikuler, serta kegiatan keseharian di rumah dan masyarakat. Dalam konteks kegiatan belajar-mengajar di kelas, pendidikan karakter dilaksanakan dengan menggunakan pendekatan terintegrasi dalam semua mata pelajaran. Khusus, untuk materi Pendidikan Agama dan Pendidikan Kewarganegaraan - karena memang misinya adalah mengembangkan nilai dan sikap - pengembangan karakter harus menjadi fokus utama yang dapat menggunakan berbagai strategi/metode pendidikan karakter (Pemerintah RI 2010, 30-31; Kemdiknas 2010, 26).

Dalam kaitan ini, peran Islam dan pendidikan agama Islam secara khusus penting untuk dikaji. Pendidikan agama Islam memiliki peran yang sangat penting dan strategis dalam menentukan arah pembentukan dan pembangunan karakter bangsa Indonesia bukan hanya karena Islam merupakan agama yang dianut mayoritas bangsa Indonesia, tetapi juga karena Islam, sebagaimana diyakini oleh pemeluknya, menyediakan sumber bagi nilai-nilai luhur universal, yang dapat menghasilkan kebaikan bukan hanya bagi pemeluknya, tetapi juga bagi seluruh umat manusia. Kedamaian, toleransi, cinta kasih, kejujuran, penghargaan dan kerjasama adalah di antara sebagian nilai luhur yang terkandung dalam ajaran Islam.

Meskipun Islam mengandung berbagai nilai luhur yang telah disebutkan, namun pada kenyataannya nilai-nilai luhur tersebut masih belum tercermin dalam karakter dan perilaku bangsa Indonesia, yang mayoritas adalah penganut agama Islam, seperti antara lain ditunjukkan dengan masih maraknya kasus korupsi, kekerasan, dan intoleransi atas nama agama. Sementara di sisi lain, kesalehan ritual menjadi fenomena yang begitu kasat mata, dalam bentuk maraknya perayaan harihari besar keagamaan, banyaknya jumlah jamaah yang berkunjung ke tempat ibadah, serta semakin banyaknya jumlah jamaah yang menunaikan ibadah haji ke tanah suci Makkah. Hal ini tentu menimbulkan keprihatinan sekaligus pertanyaan tentang sejauh mana efektivitas peran pendidikan agama Islam dalam membentuk karakter dan kepribadian bangsa Indonesia. Apakah keberhasilan pendidikan agama Islam baru sebatas meningkatkan kesalehan ritual semata?

Di tengah kondisi masih kontrasnya antara nilai-nilai ideal agama (Islam) dan perilaku pemeluknya, sebagian elemen masyarakat telah menggulirkan inisiatif untuk mendorong pengembangan karakter bangsa dengan cara mempromosikan proses pembelajaran berbasis nilai di lembaga pendidikan, baik lembaga pendidikan 
umum, seperti sekolah dan perguruan tinggi, maupun lembaga pendidikan berciri agama, seperti madrasah dan pesantren. Inisiatif yang dikenal dengan nama Pendidikan Menghidupkan Nilai (Living Values Education) ini antara lain dilakukan oleh Yayasan Wakaf Paramadina, Lembaga Studi Agama dan Filsafat (LSAF), Pusat Kajian Agama dan Budaya (Puskadiabuma) UIN Yogyakarta, Lembaga Kajian Islam dan Sosial (LKiS), dan Yayasan Matapena Yogyakarta.

Sejak 2009 hingga saat ini, program Pendidikan Menghidupkan Nilai yang dijalankan oleh sejumlah lembaga swadaya masyarakat dengan dukungan Yayasan Asia itu telah berlangsung di berbagai sekolah dan pesantren di berbagai wilayah, antara lain Kabupaten Rangkasbitung (Banten), Kabupaten Bogor, Garut, Cirebon (Jawa Barat), Kabupaten Sleman dan Gunung Kidul (Yogjakarta), dan Kota Wonosobo (Jawa Tengah). Jumlah tenaga pendidik yang telah mengikuti pelatihan Pendidikan Menghidupkan Nilai hingga saat ini mencapai sedikitnya 1.489 orang, termasuk dari kalangan dosen.

Inisiatif Pendidikan Menghidupkan Nilai penting dikaji berdasarkan sejumlah alasan. Pertama, inisiatif yang lahir dari partisipasi masyarakat itu sejalan dengan gerakan nasional pendidikan karakter yang saat ini tengah digulirkan pemerintah. Inisiatif itu bertujuan untuk mempromosikan pembelajaran berbasis nilai, baik di lingkup pribadi, sekolah, maupun komunitas. Kedua, seperti halnya pendidikan karakter yang dikampanyekan Pemerintah melalui Kementerian Pendidikan dan Kebudayaan, Pendidikan Menghidupkan Nilai tidak dirancang untuk menjadi mata ajar tersendiri, melainkan diintegrasikan ke dalam seluruh kurikulum pembelajaran. Terkait hal ini, penting untuk mengetahui apakah program Pendidikan Menghidupkan Nilai dapat dimanfaatkan untuk meningkatkan kualitas pembelajaran Pendidikan Agama Islam (PAI) di sekolah dalam rangka mendukung tujuan pendidikan karakter bangsa yang saat ini tengah digalakkan oleh pemerintah.

Dalam rangka memberi kontribusi bagi pengembangan PAI dalam rangka pendidikan karakter, peneliti bermaksud mengkaji pelaksanaan program Pendidikan Menghidupkan Nilai (PMN) yang telah dan sedang dilaksanakan oleh sejumlah LSM dan lembaga pendidikan. Penelitian ini mengkaji apakah program Pendidikan Menghidupkan Nilai itu dapat dimanfaatkan untuk mendukung peningkatan kualitas PAI sebagai instrumen pendidikan karakter. Penelitian dilakukan dengan melakukan studi kasus terhadap pelaksanaan program Pendidikan Menghidupkan Nilai di Sekolah Madania, Parung, Bogor. Alasan pemilihan kasus ialah karena Sekolah Madania adalah termasuk mitra dari lembaga pendidikan berbentuk sekolah yang mengikuti program ini, sementara di wilayah lain program ini lebih banyak melibatkan mitra dari lembaga pendidikan berbentuk pesantren. Di Sekolah Madania, implementasi program Pendidikan Menghidupkan Nilai dalam kaitannya dengan PAI sebgai mata ajar lebih dapat teramati.

Permasalahan pokok yang hendak dijawab melalui penelitian ini ialah apakah program Pendidikan Menghidupkan Nilai dapat menyediakan contoh yang berguna bagi upaya pengembangan Pendidikan Agama Islam sebagai instrumen utama pendidikan karakter di lingkungan sekolah?

Pertanyaan tersebut akan dijawab dengan mengkaji: 1) nilai-nilai apa yang dikembangkan melalui program Pendidikan Menghidupkan Nilai? 2) pendekatan dan aktivitas apa yang digunakan rangka pengembangan dan penggalian nilai? 3) dampak apa yang dihasilkan program tersebut terhadap sikap dan perilaku peserta didik serta terhadap kebijakan sekolah terkait pengembangan karakter komunitas sekolah?

Penelitian ini bertujuan untuk mengkaji pelaksanaan program Pendidikan Menghidupkan Nilai di Sekolah Madania, Parung, Bogor. Secaralebih spesifik, penelitian ini bertujuan untuk mengkaji apakah program Pendidikan Menghidupkan Nilai itu menghasilkan good practices bagi pengembangan model pembelajaran Pendidikan Agama Islam dalam rangka pendidikan karakter di lingkungan sekolah.

Penelitian ini diharapkan dapat menghasilkan informasi berguna bagi pengembangan modelmodel Pendidikan Agama Islam dalam rangka pendidikan karakter di lingkup satuan pendidikan sekolah. Hasil penelitian ini juga diharapkan dapat memberi kontribusi bagi gerakan nasional pendidikan karakter yang saat ini sedang dicanangkan oleh pemerintah, khususnya melalui Kementerian Agama maupun Kementerian Pendidikan dan Kebudayaan.

\section{METODE PENELITIAN}

Penelitian ini dilakukan dengan menggunakan pendekatan studi kasus terhadap pelaksanaan program Pendidikan Menghidupkan Nilai yang dilaksanakan di Sekolah Madania, Parung, Bogor. Studi kasus ini bersifat evaluatif (Bassey 1999:59; Yin 2003: 127-133) karena studi kasus ini digunakan untuk menilai atau mengevaluasi apakah 
program Pendidikan Menghidupkan Nilai tersebut menyediakan praktik yang baik (good practices) bagi pengembangan model pembelajaran Pendidikan Agama Islam dalam rangka pendidikan karakter.

Teknik pengumpulan data melibatkan kombinasi antara analisis terhadap berbagai dokumen pelaksanaan dan hasil evaluasi program; wawancara dengan pengelola program, dan tenaga pendidik; serta pengamatan terhadap kondisi sekolah dan kegiatan belajar-mengajar.

Selanjutnya seluruh data dan informasi yang diperoleh akan dianalisis dengan menggunakan teknik analisis deskriptif-komparatif. Dengan teknik ini, seluruh hasil temuan disajikan secara deskriptif sekaligus dilakukan komparasi atau perbandingan dengan berbagai data dan temuan yang diperoleh dari berbagai sumber lainnya.

\section{Tinjauan Pustaka}

Dalam berbagai literatur, istilah pendidikan karakter sering dipertukarkan dengan istilah pendidikan nilai, pendidikan budi pekerti, pendidikan moral, pendidikan watak dan pendidikan etika. Untuk menghindari kebingungan, maka diperlukan klarifikasi terlebih dahulu terhadap beberapa istilah kunci tersebut.

Dalam Tesaurus Bahasa Indonesia Pusat Bahasa (2008: 229), kata "karakter" mengacu pada berbagai makna, yaitu "bawaan, hati, jiwa, kepribadian, budi pekerti, perilaku, personalitas, sifat, tabiat, temperamen, watak." Selain itu, kata "karakter" juga diasosiasikan dengan "ciri, karakteristik, keunikan". Berdasarkan makna-makna tersebut, kata "berkarakter" dimengerti sebagai "berkepribadian, berperilaku, bersifat, bertabiat, atau berwatak." Dengan demikian, karakter mengacu pada dua dimensi dari kedirian manusia yang saling terkait, yaitu dimensi dalam (watak, sifat atau tabiat) dan dimensi luar (perilaku). Karakter hanya dapat teramati lewat perilaku, sebaliknya perilaku merupakan fenomena yang menunjukkan karakter, sifat atau watak seseorang.

Adapun kata "nilai" dalam Tesaurus tersebut memiliki makna yang lebih beragam lagi, namun yang paling relevan dengan pembahasan ini ialah "nilai" dalam pengertian "timbangan dan ukuran" (Pusat Bahasa 2008: 337). Apabila kata "nilai" dikaitkan dengan "karakter", maka nilai mengandung pengertian "ukuran atau pedoman berperilaku". Dengan kata lain, nilai adalah ukuran yang digunakan untuk menilai apakah karakter atau perilaku seseorang dipandang sebagai baik atau buruk, dikehendaki atau tidak dikehendaki. Pengertian tersebut sejalan antara lain dengan definisi nilai (values), yaitu "prinsip-prinsip dan keyakinan-keyakinan dasar yang menjadi pedoman bagi perilaku, di mana prinsip dan keyakinan itu menjadi ukuran yang digunakan untuk menilai apakah suatu tindakan tertentu dipandang baik (good) dan dikehendaki (desirable)." Prinsip dan keyakinan tentang hal yang baik dan buruk ini juga terkandung dalam pengertian dari kata "moral" atau "moralitas" (Pusat Bahasa 2008: 324).

Dengan demikian, kendati istilah yang digunakan kerap berbeda, namun secara umum pendidikan nilai, pendidikan karakter, pendidikan watak, pendidikan budi pekerti, pendidikan akhlak atau pendidikan etika sesungguhnya mengandung pengertian yang relatif sama, kendati aspek yang ditekankan berbeda-beda.

Terlepas dari perbedaan penggunaan istilah, pendidikan karakter atau pendidikan nilai umumnya dipahami bukan hanya sebagai proses transfer pengetahuan tentang hal yang baik atau hal yang buruk, hal yang seharusnya dilakukan dan hal yang seharusnya dihindari. Dalam rumusan yang dibuat oleh Kementerian Pendidikan dan Kebudayaan (dh. Kementerian Pendidikan Nasional), pendidikan karakter “...bukan sekedar mengajarkan mana yang benar dan mana yang salah, lebih dari itu pendidikan karakter menanamkan kebiasaan (habituation) tentang hal yang baik sehingga peserta didik menjadi paham (domain kognitif) tentang mana yang baik dan salah, mampu merasakan (domain afektif) nilai yang baik dan biasa melakukannya (domain perilaku)" (Kerangka Acuan Pendidikan Karakter Kemdiknas 2010: 10).

Sementara itu Pemerintah Australia mendefinisikan pendidikan nilai sebagai "setiap aktivitas berbasis sekolah yang secara eksplisit dan/ atau implisit mempromosikan pemahaman dan pengetahuan siswa tentang nilai, dan menanamkan ketrampilan dan kecenderungan pada diri siswa sehingga mereka dapat mengejawantahkan nilainilai tertentu sebagai individu maupun sebagai anggota komunitas yang lebih luas" (DEST 2003: 2, dikutip dalam Lovat Toomey, eds. 2009: xii). Dengan demikian, pendidikan nilai atau pendidikan karakter bukan sekadar proses transmisi pengetahuan atau nilai, tetapi melibatkan pula upaya penggalian nilai dan pembiasaan (habituasi).

Seperti telah dikemukakan, sekolah memiliki peran penting dalam proses pendidikan nilai. Secara khusus, para ahli menyebut peran sentral guru dalam pendidikan nilai atau pendidikan karakter karena "nilai merupakan bagian integral proses pengajaran, yang tercermin dalam apa yang diajarkan dan juga dalam cara guru berinteraksi dengan siswa" 
(Leenders and Wiel Veugelers, 2009: 22-23). Sangat penting bagi guru memiliki pengetahuan dan menguasai ketrampilan dalam hal pendekatan, strategi dan metode untuk pembelajaran dan penggalian nilai. Lebih dari itu, peran penting guru juga terkait dengan posisinya sebagai teladan bagi peserta didik menyangkut bagaimana seharusnya nilai-nilai digali, dikembangkan dan diimplementasikan. Keberhasilan pendidikan nilai di sekolah, dalam banyak hal, akan sangat terkait dengan pengajaran yang berkualitas (quality teaching) (Lovat, 2009: 1-11). Oleh sebab itu, sarjana lain menekankan pentingnya guru untuk mendapat pendidikan dan pelatihan yang berkualitas pula (Gellel, 2010:163-177).

Selain aspek nilai yang dikembangkan (aspek substansi) dan cara nilai itu dikembangkan (aspek metodologi atau pendekatan), para pengkaji juga memberi penekanan pada aspek hasil yang dicapai melalui pendidikan nilai (aspek dampak). Beberapa peneliti telah mengembangkan berbagai cara untuk mengukur hasil atau dampak dari pendidikan nilai, baik melalui penelitian kuantitatif maupun kualitatif. Beberapa hasil dari pendidikan nilai yang ditemukan para pengkaji dalam riset mereka tentang implementasi pendidikan nilai di sekolah-sekolah di Australia antara lain dampak pendidikan nilai terhadap kesadaran tentang nilai (value consciousness), kondisi siswa yang 'sehat' (well-being), keberdayaan (agency), keterkaitan (connectedness) dan transformasi (transformation) (VASP 2010). Yang dimaksud dengan konsisi siswa yang 'sehat' ialah siswa memiliki rasa percaya diri serta hasrat untuk mempelajari hal-hal baru dan memperoleh ketrampilan-ketrampilan baru (Hill, 2010: 650).

Berdasarkan tinjauan terhadap sejumlah literatur di atas, dalam konteks penelitian ini, kerangka konseptual yang dikembangkan sebagai acuan penelitian ini dapat digambarkan sebagai berikut:

Gb.1: Kerangka konseptual riset pendidikan nilai

\begin{tabular}{|c|c|c|}
\hline Substansi & Metodologi & Hasil \\
\hline \multirow[t]{4}{*}{ Nilai-nilai } & Pendekatan & Guru \\
\hline & Metode & Siswa \\
\hline & Aktivitas & Sekolał \\
\hline & Evaluasi & \\
\hline
\end{tabular}

Berdasarkan kerangka konseptual di atas, ada tiga aspek utama yang hendak dikaji dari Program Pendidikan Menghidupkan Nilai, yaitu aspek substansi, metodologi, dan hasil.

\section{Substansi}

Substansi dari Program Pendidikan Menghidupkan Nilai dan program sejenisnya seperti pendidikan karakter adalah nilai-nilai yang hendak digali dan dikembangkan melalui proses pembelajaran. Seperti telah disinggung sebelumnya, masing-masing masyarakat atau negara memiliki prioritas nilai yang berbeda. Pemerintah Australia, misalnya, menetapkan 9 nilai yang akan dikembangkan melalui pendidikan nilai di sekolahsekolah di Australia, yaitu (1) kepedulian dan kasih-sayang, (2) berbuat terbaik, (3) berlaku adil, (4) kebebasan, (5) kejujuran dan dapat dipercaya, (6) integritas, (7) penghargaan, (8) tanggungjawab dan (9) pemahaman, toleransi dan inklusi. Adapun Pemerintah Indonesia menetapkan 18 nilai yang akan dikembangkan melalui penddikan karakter, yaitu: (1) religius, (2) jujur, (3) toleransi, (4) disiplin, (5) kerja keras, (6) kreatif, (7) mandiri, (8) demokratis, (9) rasa ingin tahu, (10) semangat kebangsaan, (11) cinta tanah air, (12) menghargai prestasi, (13) bersahabat/komunikatif, (14) cinta damai, (15) gemar membaca, (16) peduli lingkungan, (17) peduli sosial dan (18) tanggung jawab (Pusat Kurikulum, 2009: 9-10). Meski ada perbedaan dalam nilai-nilai yang dipromosikan antara kedua pemerintah, namun ada pula kesamaan, seperti kepedulian, kejujuran dan tanggungjawab.

Salah satu pertanyaan yang hendak dijawab melalui penelitian ini ialah nilai-nilai apa yang dikembangkan melalui Program Pendidikan Menghidupkan Nilai, dan apakah persamaan dan perbedaan dengan nilai-nilai yang dikembangkan melalui program pendidikan sejenis, antara lain yang dikembangkan oleh Pemerintah Indonesia dan Pemerintah Australia. Hal lain yang juga hendak digali terkait aspek substansi ialah persepsi guru Pendidikan Agama Islam terhadap butir-butir nilai yang dikembangkan melalui program Pendidikan Menghidupkan Nilai. Apa pandangan guru-guru PAI tentang butir-butir nilai PMN? Bagaimana mereka mendialogkan nilai-nilai tersebut dengan nilai-nilai luhur yang bersumber dari ajaran Islam seperti yang mereka pahami selama ini? Apakah dalam persepsi guru-guru PAI program Pendidikan Menghidupkan Nilai itu dapat memberi kontribusi bagi pengembangan Pendidikan Agama Islam sebagai instrumen utama pendidikan karakter di sekolah? 


\section{Metodologi}

Para ahli telah mengembangkan sejumlah pendekatan dalam proses pembelajaran nilai di sekolah. Pendekatan itu antara lain mencakup pendekatan watak (trait approach), pendekatan penanaman nilai (values inculcation approach), pendekatan perkembangan kognitif (cognitive development approach), pendekatan klarifikasi nilai (clarification of values approach), dan pendekatan pratik atau aksi (service learning approach).

Pendekatan watak didasarkan atas gagasan bahwa ada sejumlah kualitas atau sifat yang telah ditetapkan sebelumnya yang menentukan orang bermoral. Sifat-sifat tersebut bersifat 'mutlak' dalam arti praktik tindakan yang diekspresikan melalui sifat-sifat tersebut merupakan perilaku moral yang 'tepat', 'baik' atau dapat diterima. Adapun pendekatan penanaman nilai ialah pendekatan yang digunakan untuk menanamkan nilai-nilai yang diterima secara sosial pada diri siswa melalui pengajaran atau transmisi langsung maupun secara tidak langsung melalui praktik-praktik rutin di kelas, model peran, penguatan, pujian, permaian dan simulasi, serta permaian peran.

Sementara itu, pendekatan perkembangan kognitif atau pertumbuhan moral merupakan pendekatan untuk mengembangkan lebih jauh nilainilai pada diri siswa dengan mempertimbangkan tahapan perekembangan moral mereka, melalui aktivitas seperti diskusi kelompok kecil, aktivitas dilema, tugas membuat keputusan, dan sebagainya. Pendekatan klarifikasi nilai menggunakan aktivitasaktivitas praktis untuk mengklarifikasi atau memperjelas perasaan terhadap orang/peristiwa/ permasalahan. Terakhir, pendekatan praktik atau aksi berpijak pada asumsi bahwa sekolah seharusnya menyediakan peluang bagi siswa untuk mempraktikkan tindakan membuat keputusan untuk memilih suatu perbuatan tertentu. Terkait aspek metodologi, penelitian ini hendak mengkaji pendekatan dan metode apa yang digunakan dalam program PMN? Apakah pendekatan yang digunakan dapat dikategorikan ke dalam salah satu pendekatan yang telah dikemukakan di atas? Bentuk akvititas atau kegiatan apa yang dilakukan dalam rangka pengembangan dan penggalian nilai? Sumber atau bahan-bahan apa yang digunakan sebagai materi pokok maupun materi penunjang pembelajaran?

Selain metode pembelajaran, penelitian ini juga akan melihat metode evaluasi yang digunakan untuk mengukur keberhasilan program ini. Hasil (outcomes) dan dampak (impacts) menjadi tolok ukur apakah proses pembelajaran nilai dapat dikatakan berhasil atau tidak. Metode evaluasi apa yang digunakan dan indikator keberhasilan atau indikator kinerja apa yang digunakan? Para ahli telah menggunakan berbagai jenis penelitian dalam upaya mengidentifikasi hasil dan dampak program pendidikan nilai yang dilakukan di berbagai negara. Di Australia, baik pendekatan kuantitatif berupa survei mapun pendekatan kualitatif dengan menggunakan teknik 'MSC (most significant change) stories' telah digunakan untuk menilai hasil dan dampak yang dicapai program pendidikan nilai di berbagai sekolah (Lovat et al 2009; VASP 2010).

\section{Hasil}

Beberapa hasil riset memperlihatkan bahwa pendidikan nilai memiliki dampak pada sejumlah hal seperti kesadaran akan nilai (values consciousness), sikap murid dan guru yang 'sehat' (student and teacher well-being), kondisi lingkungan sekolah yang tenang dan damai (school ambience), hubungan guru-murid yang baik, dan partipasi orang tua dan keluarga. Temuan lain yang menarik ialah dampak pendidikan nilai terhadap kecerdasan akademis siswa (VASP 2010; Lovat et al 2009; Lovat and Toomey, eds. 2010).

Hasil dan dampak akan bergantung pada proses pembelajaran yang dilaksanakan sehingga hasil dan dampak itu akan bervariasi, bukan saja dari satu negara ke negara lain, tetapi bahkan dari satu sekolah ke sekolah lain dalam satu negara yang sama. Oleh sebab itu, penting pula melihat hasil dan dampak dari program Pendidikan Menghidupkan Nilai, dan membandingkannya dengan hasil dan dampak yang diperoleh dari program-program pendidikan nilai lainnya. Dalam penelitian ini, hasil atau dampak yang hendak dikaji dibagi ke dalam tiga lingkup, yaitu peserta didik, tenaga pendidik, dan sekolah.

\section{PEMBAHASAN \\ Program Pendidikan Menghidupkan Nilai}

Pendidikan Menghidupkan Nilai atau LVE (Living Values Education) berawal dari proyek internasional yang dimulai pada 1995 oleh Yayasan Brahma Kumaris dalam rangka merayakan ulang tahun ke-50 Perserikatan Bangsa-Bangsa (PBB). Proyek yang saat itu bernama Sharing Our Values for a Better World (Berbagi Nilai-nilai Kita untuk Dunia yang Lebih Baik). Tema proyek itu diambil dari pasal dalam Pembukaan Deklarasi PBB yang berbunyi: "To reaffirm faith in fundamental human rights, in the dignity and worth of the human person..." (Untuk memperkokoh keyakinan pada hak-hak asasi manusia, martabat dan nilai seorang manusia...). Sebagai bagian dari proyek itu, ditulis buku Living Values: A Guide Book, yang berisi 
penjelasan dari nilai-nilai inti yang dikembangkan, termasuk aktivitas-aktivitas penunjang.

Untuk memenuhi kebutuhan pendidikan nilai berbasis sekolah, pada Agustus 1996 dua puluh pengajar dari seluruh dunia berkumpul di kantor UNICEF di New York, membentuk LVEI (Living Values: An Education Intiative). Mereka mendiskusikan kebutuhan para murid, pengalaman mereka mengajarkan nilai-nilai, dan bagaimana para pengajar mengintegrasikan nilai-nilai guna menyiapkan para murid untuk proses pembelajaran seumur hidup. Dengan menggunakan Living Values: A Guide Book dan Convention on the Rights of the Child (Konvensi Hak Anak) sebagai kerangka kerja, para pengajar mengidentifikasi dan menyepakait tujuan pendidikan nilai berbasis sekolah di seluruh dunia, baik untuk negara maju maupun berkembang. Akhirnya pada Februari 1997, Living Values Educator's Kit siap digunakan, dan sejak saat itu LVEP mulai dijalankan. Sampai Maret 2000, LVEP telah dilaksanakan di 1.800 lokasi yang tersebar di 64 negara (Tillman, 2004: ix-xii). Pada 2004, dibentuklah wadah bagi para pendidik yang telah bekerja untuk Pendidikan Menghidupkan Nilai, yang diberi nama Association for Living Values Education International (ALIVE International) yang berkantor pusat di Jenewa, Swiss (lihat http:// www.livingvalues.net; diakses 30 Oktober 2012).

Living Values Education (LVE) pertama kali dikembangkan di Indonesia oleh Helen Quirin pada tahun 2002. Saat itu beliau banyak mendengar tentang metode LVE yang dipraktikan di beberapa sekolah di luar negeri seperti Singapura, sehingga beliau terpikir untuk mengembangkan LVE di Indonesia. Beberapa waktu kemudian, pada saat beliau berada di Singapaura, salah seorang temannya memberikan lima buah buku LVE untuk dikembangkan di Indonesia.

Setiba di Indonesia, Helen menunjukan kelima buku tersebut kepada seorang kepala sekolah yang sedang mendirikan sekolah baru bernama Universal yang terletak di Kemayoran, tepatnya di belakang sekolah Gandhi. Setelah membacanya, kepala sekolah tersebut tertarik untuk mengembangkan konsep dan metode LVE dan meminta Helen untuk memberikan pelatihan bagi para guru-guru di sekolahnya itu. Mengingat Helen saat itu baru mengenal LVE, sehingga belum memahami bagaimana memberikan pelatihan LVE untuk para guru. Kemudian ia mengontak salah seorang temannya yang bernama Ruth yang berasal dari Korea, yang saat itu kebetulan sedang berada di Singapura untuk memberikan training LVE bagi para guru-guru tersebut.
Training kemudiaan diadakan dengan melibatkan 40 orang guru yang dilaksanakan di Graha Sindu, Jl. Taman Hudi, Pasar Baru selama dua setengah hari. Setelah training selesai, kepala sekolah meminta Helen untuk mengajar LVE dari kelas satu sampai kelas sepuluh setiap dua kali dalam seminggu. Helen mengajar dengan mengembangan setiap nilai pada setiap bulannya, seperti bulan pertama ia mengembangkan nilai kedamaian, bulan kedua nilai pengharagaan dan seterusnya. Kemudian setelah beberapa bulan kemudian, Helen meminta suatu ruangan tersendiri yang di dalamnya ada karpet, di sana ia mengajarkan aktivitas nilai dengan meminta anak-anak untuk membuat gambar bermuatan nilai, seperti burung merpati yang merupakan simbol kedamaian dengan menggambar pada sayap-sayapnya benderabendera dari beberapa negara serta melakukan aktivitas-aktivitas nilai lainnya.

Kemudian LVE berkembang sangat baik di Sekolah Al-Izhar yang dikembangkan oleh Ibu Irma Makarim dan Taka Gani. Setelah itu, berbagai kegiatan, seminar dan pelatihan Living Values Education kemudian dilakukan di banyak kota di Indonesia. Mulai dari Banda Aceh, Tapaktuan, Jakarta, Bogor, Bandung,Subang, Sukabumi, Yogyakarta, Salatiga, Solo, Kupang, Tabanan, Singaraja, sampai di Ambon dan Ternate. Program dan aktivitas Living Values Education tersebut tidak hanya dilakukan dalam lingkungan pendidikan, namun juga di kamp pengungsian, dalam komunitas maupun institusi lainnya.

Pada tanggal 1 Desember 2008, Yayasan Karuna Bali ditunjuk menjadi perwakilan Asosiasi Living Values Education di Indonesia oleh ALiVE (Asosiasi LVE) Internasional. Yayasan Karuna Bali mengemban tugas sebagai payung hukum, mengeluarkan akreditasi pelatih dan mengkoordinasi kegiatan-kegiatan Living Values Education di Indonesia (diakses 30 Oktober 2012).

\section{Pendidikan Menghidupkan Nilai di Sekolah Madania}

Sekolah Madania berada di bawah naungan Yayasan Pendidikan Madania Indonesia (YPMI) yang berdiri pada 1995. Para pendiri yayasan tersebut ialah Prof. Dr. Nurcholish Madjid (alm.), Drs. Achmad Fuadi, dan Prof. Dr. Komaruddin Hidayat. Kata 'Madania' berasal dari bahasa Arab, 'Madaniah', yang memiliki akar kata yang sama dengan 'Madinah', yang berarti 'peradaban'. Madinah sendiri berarti tempat peradaban, yang sering diartikan sebagai 'kota', yaitu suatu tempat yang dihuni oleh masyarakat yang berperadaban, penuh ketaatan, disiplin, dan tunduk-patuh kepada Tuhan. 
Baik 'madinah' maupun 'madaniah' merupakan kata turunan dari kata dasar dāna, yadìnu, dìnan, yang berarti taat, tunduk, patuh, dan pasrah. 'Madinah' maupun 'madaniah' juga bisa berasal dari kata dasar madana, yamdunu, madyinah, yang berarti membangun, yaitu membangun peradaban. Lihat booklet sekolah Madania: Indonesian School with World Class Standard (t.t.), h. 3. Lihat juga informasi lebih jauh mengenai Madania di (http://www. madiania.net.; diakses 15 November 2012).

Menurut penjelasan Wahyuni Nafis, MA, yang menjabat sebagai Principal Sekolah Madania saat ini, sekolah Madania bermula dari ide Nurcholish Madjid (yang akrab disapa dengan Cak Nur) yang merasa prihatin melihat banyaknya lembaga pendidikan Islam, namun jarang di antara lembaga pendidikan itu yang mampu mengungguli lembagalembaga pendidikan seperti yang dikelola oleh umat lain. "Banyak lembaga pendidikan Islam, menurut Cak Nur, tidak memberikan perhatian pada aspek kualitas, tetapi lebih pada pendidikan yang masih mempertahankan cara-cara atau pendekatan yang konvensional. Hal di atas harus dicarikan jawabannya. Madania akhirnya berdiri sebagai wujud dari cita-cita mulia Cak Nur semasa hidupnya," kata Nafis (Wawancara, M. Wahyuni Nafis, MA, principal Sekolah Madania; tanggal 8 Oktober di Parung, Bogor)

Pendidikan Madania berusaha memberikan fasilitas dan bimbingan bagi pertumbuhan intelegensi siswa secara utuh, sehingga ukuran keberhasilan anak didik tidak diukur secara seragam, melainkan sesuai dengan potensi dan minat masing-masing. Di Madania, pendidikan karakter sangat dipentingkan karena pendidikan life skill, disamping special skill, akan sangat diperlukan dalam kehidupan mendatang yang penuh perubahan. Pada 2003, menurut Wahyuni Nafis, Madania telah merumuskan Moral Values Education menjadi kurikulum, serta mengajarkan nilai-nilai, baik pada pelajaran agama maupun pelajaran umum lainnya. Pada tahun-tahun berikutnya, tahun 2007-2008, Madania menambah jam evaluasi proses belajar mengajar dari aspek kognitif, afektif maupun psikomotorik dengan cara semua guru harus terlibat menilai karakter siswa, misalnya: apakah kemandirian anak dan integritas anak dalam masing-masing pelajaran yang dipandu oleh guru-guru bersangkutan itu muncul (Wawancara dengan M. Wahyuni Nafis, MA; tanggal 8 Oktober di Parung, Bogor).

Sekolah Madania mulai mengenal Pendidikan Menghidupkan Nilai (PMN) pada 2004 ketika mengundang Yayasan Brahma Kumaris untuk memberi pelatihan kepada guru dan manajemen sekolah. Lalu pada 2010-2012, Sekolah Madania menjalin kerjasama dengan Yayasan Wakaf Paramadina dan Yayasan Asia untuk pelaksanaan pelatihan PMN bagi guru dan staf manajemen sekolah dan juga evaluasi terhadap pelaksanaan program (Wawancara dengan M. Wahyuni Nafis, MA; tanggal 8 Oktober di Parung, Bogor; wawancara dengan Taufik Hidayat, manajer program LVE Yayasan Wakaf Paramadina, tanggal 2 Oktober di Jakarta).

Pelatihan PMN dalam bentuk workshop diadakan di Sekolah Madania pada 9 Januari, 20 Februari, 27 Maret, dan 24 April 2010. Peserta workshop bukan hanya dari kalangan guru, tetapi juga dari pihak manajamen sekolah. Hal ini dimaksudkan untuk memberi pemahaman bahwa tugas penggalian nilai bukan berada di pundak guru semata, juga tetapi menjadi tugas seluruh warga sekolah. Jumlah peserta yang mengikuti workshop 34 orang, terdiri dari 19 perempuan (63\%) dan 11 laki-laki (37\%). 30 orang adalah guru pada tingkat level SD, SMP, SMA, SEN-U (kelas spesial untuk anak berkebutuhan khusus), sedangkan 4 sisanya berasal dari pihak manajemen. Fasilitator workshop berasal dari Yayasan Wakaf Paramadina, Yayasan Asia, dan beberapa lembaga lain yang telah mendapat sertifikasi sebagai trainer LVE dari Association for Living Values Education Indonesia (ALIVE Indonesia).

\section{Aspek Substansi: \\ Nilai-Nilai yang Digali}

Seperti telah dikemukakan pada bagian terdahulu, kendati pendidikan nilai atau pendidikan karakter menjadi perhatian banyak pihak dewasa ini, namun fokus atau prioritas nilai masingmasing pihak cenderung bervariasi. Pemerintah Australia, misalnya, memfokuskan pada 9 nilai, sementara Indonesia memberi penekanan pada 18 nilai. Lalu, bagaimana dengan program PMN yang dipromosikan oleh ALiVE dan Sekolah Madania?

Ada 12 (dua belas) nilai yang digali dan dikembangkan melalui program Pendidikan Menghidupkan Nilai yang dipromosikan oleh ALiVE. Keduabelas nilai itu ialah: 1) Kedamaian, 2) Penghargaan, 3) Cinta, 4) Toleransi, 5) Kejujuran, 6) Kerendahan Hati, 7) Kerjasama, 8) Kebahagiaan, 9) Tanggungjawab, 10) Kesederhanaan, 11) Kebebasan, dan 12) Persatuan. Dari keduabelas nilai itu, kedamaian dan penghargaan dipandang sebagai nilai yang paling utama, dan oleh sebab itu diberi porsi waktu untuk penggalian yang lebih lama dan ditempatkan dalam urutan pertama. Seperti dikemukakan Diane Tillman (2004: xx), 
ada beberapa alasan mengapa nilai kedamaian dan penghargaan dipandang sebagai nilai yang utama:

[nilai] kedamaian harus menjadi yang pertama karena pengalaman kami membuktikan bahwa semua murid sangat memperhatikan perdamaian dunia-bahkan pada murid yang sangat sering berkelahi. Murid-murid tampaknya merasa bahwa [nilai] Kedamaian sangat sesuai dengan kehidupan sehari-hari dan menarik untuk dijalani. [Nilai] ini mengurangi "kenakalan" yang ditemui guru pada anak-anak yang "kurang termotivasi". Penghargaan adalah [nilai] kedua yang disarankan karena banyak murid yang merasa [nilai] ini menyentuh perasaan dan sangat membantu. Guru-guru merasakan bahwa para murid menjadi lebih percaya diri, lebih menghargai orang lain, dan lebih termotivasi di dalam kelas.

Alasan lain mengapa kami menyarankan dua [nilai] ini dilaksanakan di awal adalah karena dalam pelajaran yang ada dalam unit [yang menggali tentang nilai-nilai ini] terkandung ketrampilan yang akan digunakan terus pada pelajaran dalam unitunit [nilai] yang lain.

Sementara itu, nilai-nilai yang menjadi fokus pendidikan karakter di Sekolah Madania mencakup: 1) kerjasama, 2) sikap menghargai, 3) percaya diri, 4) tepaselira, 5) rasa hormat, 6) tenggang rasa, 7) rasa keterikatan, 8) daya cipta, 9) komitmen, 10) semangat, 11) keingintahuan, serta 12) kemandirian dan kebebasan. Nilai-nilai ini merupakan fokus penggalian dan pengembangan karakter bagi siswa untuk level sekolah dasar. Adapun untuk sekolah menengah, pengembangan karakter difokuskan pada 4 nilai, yaitu truth, inclusive, integrity, dan care. Nilai truth mencerminkan keyakinan akan adanya kebenaran mutlak yang diekspresikan dalam bentuk upaya menghilangkan ego (hawa nafsu) sehingga yang ada tinggal (kehendak) Tuhan. Adapun nilai inclusive mencerminkan niat dan kemampuan untuk menjadi pribadi yang menerima perbedaan secara ikhlas dalam agama, keyakinan dan kemampuan, serta keunikan pada diri sendiri dan orang lain. Nilai integrity merefleksikan niat, pemikiran, perasaan dan perbuatan yang baik dan benar, serta keberpihakan (komitmen) kepada yang baik dan benar. Sementara itu, nilai care merefleksikan niat dan kemampuan untuk peduli dan membantu orang lain demi melaksanakan pelayanan kepada seluruh umat manusia secara adil, penuh penghargaan, dan penuh rasa hormat yang diwujudkan dengan teladan dalam pengabdian dan pelayanan melalui mendidik, mengajar, menghormati, membimbing, mengarahkan, dan membantu dengan segenap kasih-sayang (Wawancara, M. Wahyuni Nafis, MA; tanggal 8 Oktober di Parung, Bogor; lihat juga lihat juga booklet Sekolah Madania, h. 6-7).

Meski nilai yang menjadi fokus pengembangan bervariasi, namun ada pula kesamaan nilai-nilai yang dikembangkan antara ALIVE, Sekolah Madania, Kemdikbud RI, dan pemerintah Australia, seperti nilai penghargaan, kejujuran, dan toleransi (tenggang rasa) (lihat Matriks 1 di bawah).

\section{Matriks 1: Perbandingan Fokus Nilai}

\begin{tabular}{lllll}
\hline NO & ALIVE & Madania & Kemdikbud Indonesia & Pemerintah Australia \\
\hline 1. & Kedamaian & Kerjasama & Religius & Kepedulian dan Kasih Sayang \\
2. & Penghargaan & Menghargai & Jujur & Berbuat terbaik \\
3. & Cinta & Percaya diri & Toleransi & Berlaku adil \\
4. & Toleransi & Tepaselira & Disiplin & Kebebasan \\
5. & Kejujuran & Rasa hormat & Kerja keras & Kejujuran dan Dapat Dipercaya \\
6. & Kerendahan Hati & Tenggang rasa & Kreatif & Integritas \\
7. & Kerjasama & Rasa keterikatan & Mandiri & Penghargaan \\
8. & Kebahagiaan & Daya cipta & Demokratis & Tanggungjawab \\
9. & Tanggungjawab & Komitmen & Rasa Ingin Tahu & Pemahaman, Toleransi, dan Inklusi \\
10. & Kesederhanaan & Semangat & Semangat Kebangsaan & \\
11. & Kebebasan & Keingintahuan & Cinta Tanah Air & \\
12. & Persatuan & Kemandirian dan & Menghargai Prestasi & \\
13. & & kebebasan & Bersahabat/Komunikatif & \\
14. & & & Cinta Damai & \\
15. & & Gembar Membaca & \\
16. & & Peduli Lingkungan & \\
17. & & Peduli Sosial & \\
18. & & Tanggungjawab & \\
\hline
\end{tabular}


Bervariasinya nilai yang menjadi fokus pendidikan nilai sesungguhnya tidak perlu dipandang sebagai masalah. Karena, fokus nilai mana yang akan dikembangkan memang sepenuhnya tergantung pada kebutuhan dan konteks di mana Pendidikan Menghidupkan Nilai dilakukan.

Dalam konteks sekolah Madania, para pengelola melihat 12 nilai yang direkomendasikan oleh ALIVE untuk digali dapat disesuaikan dengan kebutuhan atau tema pembelajaran. Selain itu, perbedaan atau variasi fokus nilai itu sebagian juga hanya disebabkan faktor perumusan redaksi yang berbeda atau penggunaan kategori yang berbeda untuk menempatkan nilai. Misalnya, nilai kedamaian. Menurut pengelola Sekolah Madania, tidak dicantumkannya nilai kedamaian secara eksplisit dalam 12 butir nilai Madania bukan berarti nilai kedamaian tidak dipandang penting. Mereka hanya berpandangan bahwa nilai kedamaian merupakan konsekuensi dari nilai-nilai lain seperti nilai penghargaan, kepedulian dan toleransi (tenggang rasa). Jika orang dapat menggali dan mengembangkan nilai dan sikap saling menghargai, toleransi, dan kepedulian terhadap sesama, maka pasti hal itu akan mendorong terwujudnya kedamaian di tengah masyarakat.

Hal yang mungkin lebih penting ialah bagaimana nilai-nilai luhur itu dapat digali, dikembangkan, dan dipelihara, sehingga nilai-nilai itu dapat memberi kontribusi nyata pada penciptaan kondisi sosial ideal yang dicita-citakan bersama. Dalam bagian berikut ini akan dibahas pendekatan, metode, aktivitas dan strategi yang digunakan untuk penggalian dan pengembangan nilai-nilai tersebut.

\section{spek Metodologi: \\ Pendekatan dan Metode \\ Pendekatan}

Baik Sekolah Madania maupun ALIVE terlihat memiliki pendekatan yang serupa untuk pendidikan nilai atau pendidikan karakter, yaitu menggunakan pendekatan terintegrasi atau lintaskurikulum (cross-curricular approach). Pendidikan nilai atau pendidikan karakter bukanlah suatu mata ajar tersendiri, melainkan diintegrasikan ke dalam seluruh kurikulum pendidikan. Oleh sebab itu, peserta pelatihan pendidikan nilai atau karakter bukan sebatas pada guru-guru yang mengampu mata pelajaran yang umumnya dianggap sebagai 'paling bertanggungjawab' untuk pengembangan karakter, seperti guru agama dan guru Pendidikan Kewarganegaraan (Wawancara, Taufik Hidayat, tanggal 2 Oktober di Jakarta; wawancara dengan Abdullah, guru PAI di Sekolah Madania, tanggal 8 Oktober Parung, Bogor). Bahkan, menurut keterangan Wahyuni Nafis, pendidikan nilai bukan saja diperuntukkan bagi guru, tetapi juga bagi seluruh staf manajemen sekolah dan tenaga pendukung lainnya, seperti office boy (Wawancara, Wahyuni Nafis, tanggal 21 Oktober di Parung, Bogor).

Selain berpijak pada pendekatan lintaskurikulum, pendidikan nilai di Sekolah Madania bersandar pada pendekatan 'penggalian nilai' (values exploration), bukan penanaman nilai (values inculcation) (tentang variasi pendekatan pendidikan nilai, lihat Zajda 2009: xix). Hal ini disebabkan karena pengelola Sekolah Madania bersandar pada filosofi tentang manusia sebagai makhluk yang diciptakan dalam kondisi suci (fitrah). Mengutip sebuah hadis Nabi, "Setiap anak dilahirkan dalam kesucian". Akibat dari fitrah ini adalah manusia menjadi hanif, yaitu cenderung kepada yang baik dan benar. Dengan demikian, pendekatan ini menolak pandangan yang mengatakan bahwa manusia pada mulanya diciptakan seperti tabula rasa atau kertas putih yang masih kosong (seperti yang dianut filosof John Locke); atau keyakinan yang memandang bahwa setiap manusia yang dilahirkan telah memiliki dosa warisan (yaitu dosa yang ditanggung umat manusia akibat kesalahan yang dilakukan Adam). Oleh sebab itu, fungsi pendidikan sesungguhnya adalah memandu manusia untuk mengenali, menggali dan menghidupkan nilai-nilai kebaikan yang sudah tertanam dalam dirinya.

\section{Ragam Aktivitas Pembelajaran}

Pendekatan 'penggalian nilai' ini dilakukan melalui beragam aktivitas pembelajaran, seperti Refleksi, Imajinasi, Latihan Relaksasi/Fokus, Ekspresi Seni, Permainan, Diskusi, Permainan Peran, Pemetaan Pikiran, Menulis Kreatif, dan Latihan Resolusi Konflik. Aktivitas refleksi bertujuan untuk mengajak peserta didik untuk merenungkan konsep nilai yang abstrak atau yang tersaji dalam berbagai ungkapan dan pribahasa. Misalnya, nilai kedamaian mengandung butir-butir refleksi seperti: "Setiap manusia berharga", "Saat kita menghargai diri sendiri, mudah untuk menghargai orang lain", dan sebagainya.

Selanjutnya melalui aktivitas Imajinasi, siswa diajak untuk membayangkan tentang suasana jika nilai-nilai yang sedang digali itu terwujud; apa yang mereka dapat rasakan dan alami. Mereka juga diminta membuat visualisasi melalui gambar 
atau lukisan. Aktivitas Imajinasi ini tidak hanya memancing kreativitas siswa, tetapi juga dapat mengundang ketertarikan pada nilai yang sedang dibahas.

Latihan relaksasi/fokus dilakukan dengan cara meminta siswa untuk diam selama beberapa menit. Tujuannya ialah agar siswa dapat merasakan kualitas dari suasana hening. Menurut Tillman, para guru sudah membuktikan bahwa latihan relaksasi/ fokus membantu para murid menjadi lebih tenang, lebih puas diri, dan lebih baik dalam berkonsentrasi pada saat belajar (Tillman 2004: xvi). Menurut pengakuan guru-guru yang telah mempraktikkan PMN di sejumlah pesantren dan sekolah, latihan ini membantu mengatasi suasana kelas yang biasanya riuh dan hingar-bingar (Wawancara, guru PAI Bpk. Abdullah tanggal 8 Oktober di Parung Bogor).

Aktivitas ekspresi seni mendorong siswa untuk dapat membayangkan dan memvisualisasikan nilai-nilai melalui berbagai aktivitas kesenian, seperti menggambar, bernyanyi, menari, bermain drama, bercerita, dan sebagainya. Aktivitas ini membuat pembelajaran tentang nilai menjadi tidak membosankan, sekaligus menumbuhkan kreativitas estetika siswa. Misalnya, siswa diminta untuk menggambarkan kue perdamaian, atau menuliskan puisi tentang kesederhanaan, atau menciptakan lagu yang mengandung nilai kerjasama, atau membuat video tentang perdamaian dan sebagainya. Seperti halnya aktivitas ekspresi seni, aktivitas permainan, selain melatih beberapa ketrampilan, seperti kreativitas dan kerjasama, juga menjadikan aktivitas pembelajaran nilai menjadi menyenangkan.

Adapun aktivitas permaian peran memberi peluang bagi siswa untuk merasakan dan mengalami nilai melalui berbagai peran yang dijalankan ataupun suasana yang dihadapi. Aktivitas permainan peran mendekatkan pembelajaran tentang nilai kepada realitas yang sesungguhnya dihadapi. Sementara itu, melalui aktivitas diskusi, siswa dapat mengekspresikan pandangannya tentang nilai yang sedang dibahas, dan bersama-sama dengan siswa lainnya dan guru pendamping, saling bertukar pandangan untuk mencapai pemahaman bersama yang lebih baik. Melalui aktivitas ini, siswa dan guru juga dapat mendiskusikan problem-problem aktual yang sedang dihadapi terkait nilai tertentu, seperti perang dan perdamaian.

Selain berbagai aktivitas di atas, ada pula aktivitas-aktivitasyang ditujukan untuk membangun suasana yang positif atau suasana berbasis nilai. Dua di antaranya ialah mengekspresikan penghargaan terhadap orang lain melalui ungkapan pujian; dan mendengar secara aktif. Ungkapan pujian dapat menciptakan perasaan bahwa seseorang dihargai dan selanjutnya memberi dorongan positif kepada orang tersebut untuk mengulangi perbuatanperbuatan baiknya di masa mendatang.

Sementara itu, aktivitas mendengar aktif dapat memberi dampak positif baik bagi pendengar maupun pembicara. Mendengar aktif mensyaratkan pendengar meninggalkan berbagai prasangka dan stereotype terhadap pembicara. Bahkan, ini juga menuntut agar pendengar 'menunda' untuk sementara segala pertanyaan atau kritik yang mungkin ia miliki terhadap pembicara. Hal ini memberi kesempatan bagi pendengar untuk bisa memiliki pengertian yang lebih baik mengenai apa yang disampaikan pembicara. Adapun bagi pembicara, tindakan mendengar aktif akan menciptakan perasaan pada diri pembicara bahwa ia dihargai oleh si pendengarnya. Suasana positif yang tercipta dari tindakan mendengar aktif akan meningkatkan kualitas komunikasi pada kedua belah pihak.

Sumber atau materi pembelajaran PMN dapat sangat beragam, mulai dari buku, koran dan majalah, internet, hingga radio maupun televisi. Untuk beberapa aktivitas, lingkungan alam pun digunakan sebagai sumber pembelajaran. Namun demikian, ALIVE International menerbitkan beberapa panduan yang dapat digunakan dalam proses pembelajaran. Buku-buku tersebut antara lain Living Values Education Activities for Children Ages 3-7, Living Values Education Activities for Children Ages 8-14, Living Values Education Activities for Children Ages Young Adults, Living Values Parent Groups: A Fasilitator Guide dan Living Values Activities for Refugees and Children-Affrectedby-War.

\section{Strategi Pengembangan Nilai Peran Guru}

Dalam mengembangkan pendidikan berbasis nilai, Madania menyadari bahwa posisi guru memiliki peran yang cukup sentral. Karena kesadaran ini, Madania sejak awal mempersiapkan guru-guru yang yang akan mendidik para siswa dengan persiapan yang memadai. Langkah pertama yang diperhatikan oleh Madania adalah penerimaan selektif para calon guru. Setelah diterima, biasanya para calon guru ini akan dididik dan dilatih selama empat bulan. Meski penguasaan materi pelajaran menjadi salah satu syarat penting agar dapat bisa 
mengajar, namun hal yang diharapkan dari para guru tentu bukan hanya soal penguasaan materi yang akan diberikan kepada para siswa. Karena itu, proses pendidikan dan pelatihan selama empat bulan untuk para guru diharapkan dapat memperkuat proses pengembangan pendidikan yang tidak hanya menekankan transfer ilmu pengetahuan tetapi juga karakter dan integritas.

Selain itu, untuk tetap menjaga kualitas para guru sebagai agen sentral proses pendidikan di Madania, mereka juga secara berkala direkomendasikan untuk mengikuti pendidikan dan pelatihan, baik yang dilakukan oleh Madania atau oleh pihak luar. Dalam skala yang lebih luas, Madania tidak hanya memerhatikan pendidikan dan pelatihan untuk para guru, tetapi juga para karyawan yang bekerja di Madania. Karena sejatinya proses pendidikan, terlebih pendidikan nilai, bukan hanya yang berlangsung di dalam kelas, tetapi juga di luar kelas atau lingkungan sekolah yang lebih luas. Secara umum, Madania betul-betul menyadari bahwa proses pendidikan yang berkualitas dimulai dari ketersediaan sumber daya yang memadai sejak awal. Tanpa itu, sebuah visi hanya menjadi harapan yang tidak pernah terwujud.

\section{Sensitif terhadap Tindakan Anti-Nilai}

Untuk menghindari sikap atau tindakan yang merusak pengembangan nilai, Madania berusaha untuk sensitif terhadap perilaku yang dianggap anti-nilai. Sensitivitas ini tentu sangat penting untuk memastikan kepada para siswa bahwa sebagai sebuah institusi pendidikan Madania tidak akan mentolerir sikap-sikap yang bertentangan dengan nilai yang dikembangkan di Madania. Sebagai contoh umum adalah paktik bullying yang dilakukan oleh siswa kepada siswa yang lain. Kampanye anti terhadap praktik bullying tidak hanya dilakukan melalui penempelan poster, tetapi juga melalui sikap sensitif terhadap segala praktik yang dianggap bullying. Tindakan yang diambil oleh Madania terhadap praktik bullying tentu saja bukan hukuman, apalagi hukuman fisik, tetapi justru memberikan pengertian secara persuasif kepada para pelaku bahwa tindakan itu bertentangan nilainilai yang dikembangkan oleh Madania.

\section{Pengembangan Nilai Kepedulian}

Salah satu hal penting yang dikembangkan oleh Madania untuk membangun kesadaran tentang pentingnya nilai kepedulian terhadap sesama adalah melalui program pelayanan terhadap masyarakat (community service). Melalui community service, Madania meminta kepada seluruh siswa untuk melakukan pelayanan kepada masyarakat selama sepuluh jam dalam satu tahun. Jenis pelayanan yang dilakukan dibuat fleksibel, tergantung pada kemampuan yang dimiliki oleh siswa itu sendiri. Sebagai contoh, jika seorang siswa memiliki kemahiran berbahasa Inggris, mereka dapat mengajarkan bahasa Inggris kepada komunitas yang dituju. Dengan program ini diharapkan para siswa dapat memiliki kepedulian terhadap sesama manusia dan kehendak saling membantu. Bentuk kepedulian tentu tidak selalu berupa materi tetapi juga bisa berupa share kemampuan yang dimiliki oleh siswa.

\section{Evaluasi di Sekolah dan di Rumah}

Dalam mengembangkan nilai kepada para siswa Madania menerapkan proses evaluasi yang dilakukan di sekolah dan di luar sekolah. Proses evaluasi yang dilakukan di sekolah dilakukan oleh para guru, sementara proses evaluasi di luar sekolah, khususnya di rumah, dilakukan oleh para wali murid. Proses evaluasi didasarkan pada standar lembaran daftar aktivitas yang diberikan oleh sekolah. Melalui lembar evaluasi ini, sekolah akan melihat apakah aktivitas yang dilakukan oleh siswa, baik di sekolah maupun di rumah sudah memenuhi standar sikap yang diharapkan. Proses ini juga menjadi cara bagi sekolah untuk melakukan evaluasi terhadap sikap para siswa dengan segala kekurangan dan kelebihannya.

\section{Aspek Hasil: \\ Metode Evaluasi dan Hasil}

Seperti telah disebut pada bagian terdahulu, beberapa hasil riset memperlihatkan bahwa pendidikan nilai memiliki dampak pada sejumlah hal seperti kesadaran akan nilai (values consciousness), sikap murid dan guru yang 'sehat' (student and teacher well-being), kondisi lingkungan sekolah yang tenang dan damai (school ambience), hubungan guru-murid yang baik, dan partipasi orang tua dan keluarga. Temuan lain yang menarik ialah dampak pendidikan nilai terhadap kecerdasan akademis siswa (VASP 2010; Lovat et al 2009; Lovat and Toomey, eds. 2010).

Evaluasi penting dilakukan untuk menilai seberapa efektif upaya-upaya Pendidikan Menghidupkan Nilai yang telah dilakukan dan untuk mengetahui kendala-kendala yang dihadapi, 
serta solusi yang mungkin diambil untuk mengatasi kendala-kendala tersebut. Bekerjasama dengan Yayasan Wakaf Paramadina dan Yayasan Asia, Sekolah Madania telah dan sedang melakukan evaluasi untuk menilai efektivitas dan dampak dari program Pendidikan Menghidupkan Nilai yang tengah dijalankan.

Selain catatan lapangan dari lembaga pendamping, yaitu Yayasan Wakaf Paramadina, evaluasi juga dilakukan melalui metode survey dan teknik 'cerita perubahan terpenting' (the most significant change stories, MSC) (tentang MSC, lihat Davies dan Dart 2005). Evaluasi jenis kedua masih berlangsung sampai saat penelitian ini dilakukan, sedangkan evaluasi jenis pertama telah dilaksanakan pada Agustus 2010, sekitar 6 bulan setelah pelatihan Pendidikan Menghidupkan Nilai dilaksanakan di Sekolah Madania.

Survei itu dilakukan terhadap 34 orang tenaga pendidik dan 106 siswa. Berdasarkan hasil survei guru, diketahui bahwa sekitar 71 persen (dari 34 orang) guru mengamati terjadinya perubahan positif pada diri siswa. Terkait nilai penghargaan, misalnya, sekitar 79 persen mengamati terjadinya perubahan positif dalam sikap siswa untuk menghargai orang lain. 82 persen guru melihat adanya perubahan positif dalam prestasi akademik siswa. 77 persen guru melihat adanya perubahan positif pada diri siswa dalam kemampuan berkomunikasi ketika terjadi perselisihan dan memiliki cara yang positif untuk mengatasi konflik. Sekitar 82 persen guru juga melihat perubahan positif pada diri siswa dalam hal kemampuan untuk berbicara dengan jujur. Dari sebanyak 12 aktivitas nilai yang diperoleh dalam pelatihan Pendidikan Menghidupkan Nilai, nilai kejujuran menjadi fokus utama kebanyakan guru (15\%), disusul nilai penghargaan dan tanggungjawab (masing-masing 12\%). (Laporan Hasil Asesmen Pendidikan Menghidupkan Nilai di Sekolah Madania, Yayasan Wakaf Paramadina bekerjasama dengan Yayasan Asia, 1 September 2010).

Berikut adalah beberapa testimoni guru tentang pelatihan Pendidikan Menghidupkan Nilai yang diikuti para guru.

Matrik 2 Testimoni Guru Peserta Pelatihan Pendidikan Menghidupkan Nilai

\begin{tabular}{|c|c|c|}
\hline No & Nama & Testimoni \\
\hline 1. & Mega Arsyianti & $\begin{array}{l}\text { Menyadari bahwa anak/siswa dikelas ingin dianggap berniali, ingin merasa aman, } \\
\text { dan butuh penghargaan tentang potensi yang mereka miliki. Ingin membuat murid- } \\
\text { murid saya menjadi orang yang lebih positif dan memberikan pengaruh positif, kepada } \\
\text { lingkungan sekitarnya sehingga suatu saat dunia kita berisi generasi-generasi "positif". } \\
\text { Menenangkan hati saya sendiri dan memuat diri saya dengan nilai-nilai positif sehingga } \\
\text { saya dapat menyebarkan nilai-nilai positif kepada orang lain. }\end{array}$ \\
\hline 2. & $\begin{array}{l}\text { Dinda Nauli } \\
\text { Nasution }\end{array}$ & $\begin{array}{l}\text { Puji Syukur, kehadiran saya dikegiatan/program ini membuat saya mengingat kembali } \\
\text { pencapaian karakter baik apa yang sudah tumbuh dengan baik dan yang belum saya } \\
\text { pupuk agar kepribadian saya semakin mengkristal dari karakter-karakter baik yang } \\
\text { ada pada diri. Dua nilai yang perlu saya pupuk adalah cinta dan bahagia. Selama ini } \\
\text { saya lupa, bahwa keduanya penting untuk terus saya hidupkan agar senantiasa menjadi } \\
\text { gudang energi. Amin! }\end{array}$ \\
\hline 3. & Nuraeni & $\begin{array}{l}\text { Saya merasa training kali ini memberi saya banyak insight, mengingat dan menguatkan } \\
\text { kembali apa yang pernah saya dapatkan dari training living values sebelumnya. Saya } \\
\text { percaya jika semua orang memahami dan mau menghidupkan nilai nilai-nilai positif } \\
\text { yang ada dalam dirinya, kita akan punya dunia yang lebih baik dengan anak-anak yang } \\
\text { kehidupannya juga lebih baik. Saya yakin, nilai-nilai itu sudah ada dalam diri setiap } \\
\text { orang. Training ini mengubah banyak hal positif dalam diri saya menjadi jauh lebih } \\
\text { positif dalam berbagai kehidupan saya. Saya lebih bersyukur dengan nilai-nilai yang } \\
\text { saya yakini dan saya ingin berbagi dengan anak-anak tentang hal positif yang diperoleh } \\
\text { dari training. Insya Allah, training ini memperkuat dan membantu saya menghidupkan } \\
\text { kembali nilai-nilai tersebut. }\end{array}$ \\
\hline 4. & Jusufi Samsuhari & $\begin{array}{l}\text { LVE (Living Values Education) yang menjadi mainstream amanat pembelajaran saya } \\
\text { menjadi lebih variatif dan bermakna, mendalam dan semoga semakin membawa } \\
\text { manfaat. }\end{array}$ \\
\hline 5. & $\begin{array}{l}\text { Abd. Hakim } \\
\text { Anshory }\end{array}$ & $\begin{array}{l}\text { Lebih menghargai keragaman sifat, perilaku, adab, pola pikir dari setiap diri manusia. } \\
\text { Lebih bersyukur bahwa dengan keragaman bisa lebih mempererat persaudaraan. }\end{array}$ \\
\hline
\end{tabular}



diselesaikan. Pada saat akan mengumpulkan ada yang tidak bisa mengerjakan tepat waktu, dengan beragam alasan. Dengan arahan dan motivasi. Selanjutnya mereka dapat lebih bertanggung jawab dalam mengerjakan tugas. Kesan dan Pesan:

a) Indahnya menjadi guru

b) Jadi semakin sayang dengan keluarga (anak dan isteri)

c) Sesi sharing juga sangat menarik, bisa berbagi pengalaman hidup. (Contoh: orang yang paling berpengaruh dalam hidup kita). Saya bisa berkaca dari pengalaman orang lain untuk menjadi pribadi yang baik dan guru yang menjadi contoh bagi murid-muridnya.

\section{Pendidikan Menghidupkan Nilai Sebagai Model Pembelajaran PAI}

Berdasarkan paparan pada bagian sebelumnya, pertanyaan yang tersisa ialah apakah Pendidikan Menghidupkan Nilai (PMN) dapat menyediakan model bagi pembelajaran Pendidikan Agama Islam (PAI)?

Peneliti berpandangan bahwa pelajaran penting dari PMN bagi upaya pengembangan model pembelajaran PAI yang lebih efektif terletak pada aspek pendekatan dan metode yang digunakan. Seperti telah dikemukakan sebelumnya, PMN menggunakan pendekatan penggalian atau eksplorasi nilai yang bersandar pada keyakinan positif terhadap manusia sebagai makhluk yang diciptakan oleh Tuhan dalam kondisi kesucian (fitrah). Keyakinan ini juga berimplikasi pada keyakinan lain bahwa pada dasarnya manusia secara alamiah akan cenderung kepada kebaikan (hanif) karena pada dirinya telah tertanam nilainilai kebaikan yang diberikan oleh Sang Pencipta pada saat penciptaan dirinya. Oleh sebab itu, fungsi utama dari pendidikan, termasuk PAI, sesungguhnya adalah mengajak manusia untuk mengenali dan menggali nilai-nilai kebaikan yang telah bersemayam pada dirinya.

Melalui beragam aktivitas pembelajaran, PMN memperkenalkan begitu banyak metode atau cara tentang bagaimana nilai-nilai kebaikan yang telah tertanam pada diri manusia itu digali dan dikembangkan sehingga dapat tercermin dalam sikap dan perilaku keseharian manusia. Di antara beragam aktivitas yang telah disebutkan antara lain meliputi refleksi, imajinasi, ekspresi seni, diskusi dan berbagi pandangan, permainan peran, pemetaan pikiran, dan sebagainya. Beragam aktivitas itu terbukti telah mampu menciptakan suasana pembelajaran nilai menjadi lebih hidup dan menyenangkan, serta lebih membekas pada diri peserta pembelajaran.

Beberapa ketrampilan, seperti mendengar aktif dan mengekspresikan pujian, juga telah menjadi beberapa cara untuk mendukung terciptanya suasana berbasis nilai yang nyata. Abdullah, guru PAI di Sekolah Madania, mengungkapkan bahwa "hasil nyata dari PMN dapat terlihat dari sikap siswa yang lebih dapat saling menghargai perbedaaan dan bekerkerjasama dalam tim. Siswa juga lebih dapat mengekpresikan diri melalui kegiatan sosial, seperti membantu di panti jompo, membersihkan masjid, dan lain-lain. Selain itu, siswa lebih terlihat bebas dalam mengemukakan pendapat walaupun tetap berpegang pada aturan yang telah ditetapkan."

Terkait dengan PAI, menarik untuk mengutip hasil survei yang dilakukan Lembaga Kajian Islam dan Perdamaian (LaKIP 2011) yang menyebutkan bahwa sekitar 27,9 persen (dari 993) siswa menyebutkan pokok bahasan tarikh/sejarah Islam sebagai pokok bahasan PAI yang tidak disukai, sementara 26,2 persen lainnya menyebut pokok bahasan al-Quran dan Hadis sebagai yang tidak disukai. Alasan utama yang dikemukakan siswa mengapa kedua pokok bahasan ini tidak disukai ialah karena cara kedua pokok bahasan itu diajarkan, yaitu penekanan pada metode hafalan. Terkait keluhan siswa semacam itu, Taufik Hidayat, manajer program PMN di Yayasan Wakaf Paramadina, mengemukan bahwa hal itu sesungguhnya dapat diatasi dengan cara mengubah metode pembelajaran dengan memanfaatkan ragam aktivitas yang telah disediakan oleh Pendidikan Menghidupkan Nilai. "Terkait dengan pokok bahasan tarikh, misalnya, jika guru dapat meningkatkan ketrampilan dalam teknikstorytelling, maka niscaya pembelajaran tarikh akan menjadi lebih menarik dan menyenangkan bagi siswa, yang pada gilirannya akan membantu siswa lebih mudah memetik nilai-nilai pelajaran dari berbagai materi pokok bahasan tarikh yang dipelajari," ungkapnya (Wawancara dengan Taufik Hidayat, tanggal 21 November di Jakarta).

Hal terakhir yang penting dikemukakan ialah perlunya sebuah community of practice, yaitu komunitas yang secara konsisten mempraktikkan 
dan mengekspresikan nilai-nilai yang telah dipelajari yang dapat menjadi model bagi pihak lain. Komunitas ini juga berperan untuk menciptakan suasana yang kondusif bagi pembelajaran dan pemeliharaan nilai. Komunitas ini bukan hanya terdiri dari para tenaga pendidik, tetapi melibatkan seluruh warga sekolah, termasuk orangtua siswa. Dengan demikian, sikap dan praktik positif yang telah dihasilkan melalui PMN dapat terus dipelihara.

\section{PENUTUP}

Beberapa temuan utama dari penelitian ini dapat diringkaskan sebagai berikut:

Pertama, berbagai pihak yang mempromosikan pendidikan nilai atau pendidikan karakter cenderung memberi penekanan yang berbeda terhadap nilai-nilai yang menjadi fokus perhatiannya. Program Pendidikan Menghidupkan Nilai yang dijalankan sejumlah lembaga swadaya masyarakat dan lembaga pendidikan di Indonesia, misalnya, memberi penekanan pada 12 nilai, meliputi 1) Kedamaian, 2) Penghargaan, 3) Cinta, 4) Toleransi, 5) Kejujuran, 6) Kerendahan Hati, 7) Kerjasama, 8) Kebahagiaan, 9) Tanggungjawab, 10) Kesederhanaan, 11) Kebebasan, dan 12) Persatuan. Sekolah Madania sendiri, yang menjadi fokus penelitian ini, menekankan nilai yang bervariasi sesuai dengan level pendidikan yang dikelolanya. Untuk jenjang sekolah dasar, nilai yang menjadi fokus meliputi: 1) kerjasama, 2) sikap menghargai, 3) percaya diri, 4) tepaselira, 5) rasa hormat, 6) tenggang rasa, 7) rasa keterikatan, 8) daya cipta, 9) komitmen, 10) semangat, 11) keingintahuan, serta 12) kemandirian dan kebebasan. Sedangkan untuk jenjang sekolah menengah, fokus hanya diberikan pada empat nilai, yaitu: 1) truth, 2) inclusive, 3) integrity, dan 4) care. Variasi fokus nilai itu sendiri bukan menjadi persoalan karena fokus nilai sangat ditentukan oleh konteks dan situasi di mana Pendidikan Menghidupkan Nilai itu akan dijalankan.

Kedua, program PMN menggunakan ragam aktivitas yang sangat kaya dalam rangka proses penggalian dan pembelajaran nilai. Jenis-jenis aktivitas itu antara lain meliputi refleksi, imajinasi, ekspresi seni, diskusi, permainan peran, pemetaan pikiran, dan berbagai aktivitas lain. Selain itu, beberapa ketrampilan lain dalam mendukung terciptanya suasana berbasis nilaijuga diperkenalkan, seperti mendengar aktif, mengungkapkan pujian, resolusi konflik, dan sebagainya.
Ketiga, program PMN menekankan pentingnya evaluasi sebagai bagian penting dan integral dari program. Karena, melalui evaluasi inilah kemajuan-kemajuan yang telah dicapai melalui program dapat dikenali. Selain itu, melalui evaluasi ini, kendala-kendala yang dihadapi program juga dapat diidentifikasi dan dicarikan solusinya. Evaluasi dilakukan secara regular pada awal, pertengahan maupun di akhir program. Selain itu, evaluasi yang melibatkan seluruh warga sekolah, termasuk orangtua siswa, menjadi bagian penting untuk menilai keberhasilan atau kemajuan yang dicapai terkait pembelajaran nilai. Hasil evaluasi yang telah dilakukan sejauh ini memperlihatkan bahwa PMN telah menghasilkan berbagai perubahan positif, baik pada guru, siswa maupun manajemen sekolah.

Keempat, program PMN memberi contoh atau model yang berguna yang dapat dimanfaatkan untuk meningkatkan kualitas pembelajaran Pendidikan Agama Islam (PAI). Dari segi nilai, banyak dari nilai yang menjadi fokus dalam PMN sebenarnya juga telah termuat dalam PAI, seperti kejujuran, penghargaan, toleransi, kasih-sayang, dan tanggungjawab. Namun, pembelajaran PAI selama ini cenderung masih miskin dari segi metode pembelajaran. Dalam kaitan ini, berbagai metode dan aktivitas pembelajaran yang telah dikembangkan PMN dapat menjadi contoh yang berguna bagi pembelajaran PAI.

Terakhir, hasil penelitian ini harus dibaca dengan mengingat bahwa penelitian ini hanya mengambil satu kasus di mana program Pendidikan Menghidupkan Nilai (PMN) ini dijalankan. Hasil penelitian ini tidak dapat digeneralisasi bahwa implementasi PMN di lembaga-lembaga pendidikan lainnya juga mencapai keberhasilan seperti yang telah dijalankan di Sekolah Madania. Diperlukan perluasan wilayah penelitian untuk dapat mendukung kesimpulan bahwa PMN secara umum dapat menjadi model pembelajaran PAI yang lebih efektif.

\section{UCAPAN TERIMA KASIH}

Tulisan yang ada ditangan pembaca ini tidak terlepas dari masukan dan saran berbagai pihak yang tidak dapat penulis sebutkan satu persatu. Atas bantuannya penulis ucapkan terima kasih terutama kepada informan penulis ketika penelitian ini dilakukan khususnya kepala sekolah Madania Parung Kabupaten Bogor beserta guru dan siswa. Kepada Pimpinan Redaksi Al Qalam terima kasih untuk terbitnya tulisan ini. 


\section{DAFTAR PUSTAKA}

Bassey, Michael. 1999. Case Study Research in Educational Settings. Buckingham \& Philadelphia: Open University Press.

Department of Education, Science and Training (DEST). 2005. The National Framework for Values Education in Australian Schools.

Gellel, Adrian. 2010. "Teachers as Key Players in Values Education: Implications for Teacher Formation." Dalam International Research Handbook on Values Education and Student Wellbeing, eds. Terence Lovat et al. London \& New York: Springer.

Hill, Brian V. 2010. "Values Education, Mental Reality Constructs and Student Wellbeing." Dalam International Research Handbook on Values Education and Student Wellbeing, eds. Terence Lovat et al. London \& New York: Springer.

Kementerian Pendidikan Nasional. 2010. Kerangka Acuan Pendidikan Karakter Tahun Anggaran 2010. Jakarta: Kementerian Pendidikan Nasional, Direktorat Jenderal Pendidikan Tinggi, Direktorat Ketenagaan.

LaKIP. 2011. Pembelajaran PAI di Sekolah: Laporan Hasil Survei. Jakarta: Lembaga Kajian Islam dan Perdamaian.

Leenders, Hélène, and Wiel Veugelers. 2009. "Different Perspectives on Values and Citizenship Education.” Dalam Global Values Education: Teaching Democracy and Peace, eds. Joseph Zajda and Holger Daun. London $\&$ New York: Springer.

Lovat, Terence, et al. 2009. "Project to Test and Measure the Impact of Values Education on Student Effects and School Ambience." Final Report for Australia Government Department of Education, Employment and Workplace Relations. The University of Newcastle, Australia, January 12th.
Pemerintah Republik Indonesia. 2010. Kebijakan Nasional Pembangunan Karakter Bangsa Tahun 2005-2025. Jakarta.

Pusat Kurikulum. 2009. Pengembangan dan Pendidikan Budaya \& Karakter Bangsa: Pedoman Sekolah. Jakarta: Kementerian Pendidikan Nasional, Badan Penelitian dan Pengembangan.

Pusat Kurikulum. 2010. Pengembangan Pendidikan Budaya dan Karakter Bangsa. Bahan Pelatihan Penguatan Metodologi Pembelajaran Berdasarkan Nilai-Nilai Budaya untuk Membentuk Daya Saing dan Karakter Bangsa. Jakarta: Kementerian Pendidikan Nasional, Badan Penelitian dan Pengembangan.

Terry Lovat. 2009. "Values Education and Quality Teaching: Two Sides of the Learning Coin." Dalam Values Education and Quality Teaching: The Double Helix Effect, eds. Terry Lovat and Ron Toomey. London \& New York: Springer.

Yayasan Wakaf Paramadina. 2010. Laporan Hasil Asesmen Pendidikan Menghidupkan Nilai di Sekolah Madania. Jakarta: Yayasan Wakaf Paramadina bekerjasama dengan Yayasan Asia.

Yin, Robert K. 2002. Case Study Research: Design and Methods. Third Edition. California: Sage Publication Inc.

Tillman, Diane. 2004. Living Values Activities for Young Adult (Pendidikan Nilai untuk Kaum Dewasa-Muda). Jakarta. PT Gramedia Widiasarana Indonesia

\section{Peraturan Perundang-Undangan}

Undang-Undang No. 20 Tahun 2003 tentang Sistem Pendidikan Nasional

Undang-Undang No. 17 Tahun 2007 tentang Rencana Pembangunan Jangka Panjang Nasional Tahun 2005-2025 